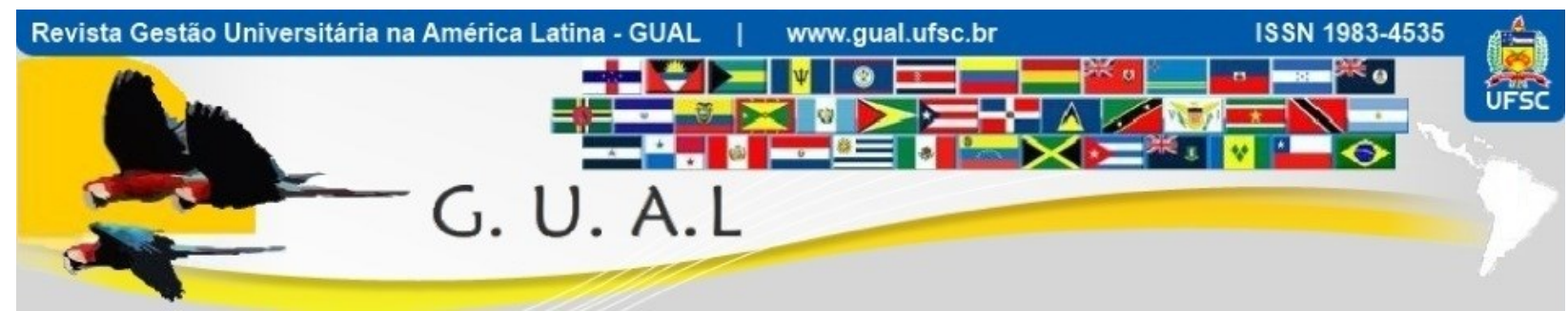

DOI: http://dx.doi.org/10.5007/1983-4535.2020v13n1p1

\title{
AWARENESS IN THE DEVELOPMENT OF INTERCULTURAL COMPETENCES AND EXISTING RELATIONSHIPS BETWEEN ATTITUDES, SKILLS AND KNOWLEDGE
}

\section{A CONSCIENTIZAÇÃO NO DESENVOLVIMENTO DAS COMPETÊNCIAS INTERCULTURAIS E AS RELAÇÕES EXISTENTES ENTRE ATITUDES, HABILIDADES E CONHECIMENTO}

\author{
Italo Cavalcante Aguiar, Mestre \\ https://orcid.org/0000-0002-6419-5551 \\ italo474@gmail.com \\ Universidade Federal do Ceará | Programa de Apoio ao Intercambista \\ Fortaleza | Ceará | Brasil \\ Romulo Alves Soares, Mestre \\ https://orcid.org/0000-0003-2412-3796 \\ romuloalves61@gmail.com \\ Universidade Federal do Ceará | Administração e Controladoria \\ Fortaleza | Ceará | Brasil \\ Luis Eduardo Brandão Paiva, Mestre \\ https://orcid.org/0000-0002-5036-6823 \\ edubrandas@gmail.com \\ Universidade Federal do Ceará | Administração e Controladoria \\ Fortaleza | Ceará | Brasil \\ Bruno de Souza Lessa, Mestre \\ https://orcid.org/0000-0002-1696-394X \\ brunolessa85@yahoo.com.br
} Universidade Federal do Rio Grande do Sul | Programa de Pós-Graduação em Administração e Controladoria Porto Alegre | Rio Grande do Sul | Brasil

Tim Rubert, Mestre https://orcid.org/0000-0001-7396-3471 tim.rubert@stratth.ac.uk University of Strathclyde | Administração de Empresas de Engenharia

Recebido em 02/outubro/2017 Aprovado em 21/dezembro/2018 Publicado em 02/janeiro/2020
José Carlos Lázaro da Silva Filho, Doutor https://orcid.org/0000-0002-8227-5491 lazaro.ufc@gmail.com Universidade Federal do Ceará | Pos-Doutorado no Zentrum Technik und Gesellschaft Fortaleza | Ceará | Brasil

Sistema de Avaliação: Double Blind Review

Esta obra está sob uma Licença Creative Commons Atribuição-Uso. 


\begin{abstract}
This research aims to examine how the exchangeists' perceptions about their abilities, knowledge and attitudes influence their awareness. In view of this, the theoretical methodological basis of Fantini (2007) is used, guided by his model of Intercultural Competence Assessment (ACI). To this end, the German and Spanish students who took part in an exchange program at the Federal University of Ceará (UFC) between 2008 and 2015 were chosen to measure their developed intercultural competences. It was obtained a sample of 159 foreign students, who exchanged in the UFC. For the treatment of the data, in addition to the descriptive and inferential statistics, the multivariate analysis of the data is used. Thus, the results show that Knowledge positively influences the students' awareness at the beginning and end of the exchange, while the Skills will negatively influence the awareness at the end of the exchange. The Attitudes component that at the beginning of the exchange influenced negatively the students' awareness at the end of the exchange began to influence positively.
\end{abstract}

Keywords: Intercultural Skills. Knowledge. Attitudes. Skills. Awareness.

\title{
RESUMO
}

Esta pesquisa objetiva examinar como a percepção dos intercambistas sobre suas habilidades, conhecimentos e atitudes influenciam a sua conscientização. Diante disso, utiliza-se a base teórica metodológica de Fantini (2007), guiando-se pelo seu modelo de Avaliação de Competência Intercultural (ACI). Para tal, foram escolhidos os estudantes alemães e espanhóis que realizaram intercâmbio na Universidade Federal do Ceará (UFC) no período entre 2008 e 2015, com o intuito de mensurar as suas competências interculturais desenvolvidas. Obteve-se uma amostra de 159 estudantes estrangeiros, que realizaram intercâmbio na UFC. Para o tratamento dos dados, utiliza-se, além da estatística descritiva e inferencial, a análise multivariada dos dados. Sendo assim, os resultados apontam que o Conhecimento influencia de maneira positiva a conscientização dos estudantes, no início e final do intercâmbio, enquanto que as Habilidades passa a influenciar negativamente a conscientização no final do intercâmbio. O componente Atitudes que no início do intercâmbio influenciava negativamente a conscientização dos estudantes, no final do intercâmbio passou a influenciar positivamente.

Palavras-chave: Competências Interculturais. Conhecimento. Atitudes. Habilidades. Conscientização. 


\section{INTRODUCTION}

Stromquist (2007) shows that, under the name of internationalization, the administrators of a private research institution (as well as external firms) emerge as powerful individuals with the ability to influence and modify academic content and thus perform "academic governance". This can be manifested in recruiting students and hiring prestigious professors and researchers to enhance the university's reputation as well as providing greater attractiveness to students by securing more research funding.

According to Woolf (2010: 45) a global citizen "generally describes someone who is, or who aspires to be intellectually engaged with other cultures, conscious of the interdependence of nations, committed to tolerance and understanding of difference," that Woolf views as "an aspirational utopian vision of the world."

From the perspective of Bhandari and Blumenthal (2011), international academic mobility is considered one of the fastest growing phenomena in higher education in the $21 \mathrm{st}$ century. Today signifcant numbers of students are currently exchanging cross-border, geographical, cultural, digital and educational boundaries in the pursuit of international education - a shift that has significant implications for higher education institutions and nations around the world.

Given these approaches, the following question for this paper arises: "What are the observable changes of German and Spanish exchange students' intercultural skills and what is the ability to raise students' awareness of this transformation?"

In this perspective, it is a general objective to examine how the exchangeists' perception of their abilities, knowledge and attitudes influences their awareness. The specific objectives delineated to achieve the general objective are: (i) to identify the intercultural competences developed by the German and Spanish students, (ii) to characterize the sociodemographic profile of German and Spanish students, according to the level of awareness about the exchange, and (iii) to analyze the relationship, during the exchange, of the components that form the model of Fantini's Intercultural Competence Assessment (2007) - knowledge, attitudes and abilities, with the component awareness between German and Spanish students.

In this research the following hypotheses are assumed: (H1) the greater the ability to speak foreign languages the greater the student's ability to develop component awareness during the exchange, $(\mathrm{H} 2)$ the knowledge component has the least influence on the awareness 
component at the end of the exchange, and (H3) the attitudes and skills components present different correlations with the awareness component at the beginning and end of the exchange.

This article is divided into five sections. Section 2 presents the literature review, which addresses intercultural competences, intercultural competency models as well as the evaluation of intercultural competences. Section 3 describes the research methodology, whereas Section 4 presents the analysis and discussion of this paper's findings. Finally, in Section 5 conclusions are drawn from the research results.

\section{REVIEW OF THE LITERATURE}

\subsection{INTERCULTURAL COMPETENCES}

According to Azevedo and Rowell (2009), competence refers to the capacity developed by the knowledgeable subject, in order to mobilize, articulate and intentionally apply knowledge (sensorial, conceptual), skills, attitudes and values in the pertinent, viable and find effective solutions. A skill is something that can be operational, procedural such as a sequence of operative modes and tought through analogies, intuition, induction, deduction, application as well as transposition. A mastered skill can further contribute to the development of various other skills. Contrary to a skill a competence presupposes the development of several different skills, including skills with a variable degree of complexity.

Considering Bertolini's (2004) perspective, it is emphasized that the competence focus is people-centered, which they learn by reflexively facing with real situations and rebuilding them on their own initiative, assuming responsibility for their work and Communication with the other. Competencies are intangible assets and abilities of an organization and their use or administration depends on their understanding of them. Therefore, it is necessary that its characteristics are modeled through explicit resources.

There are three aspects in the definition of competence: (i) the initiative and responsibility of the individual, (ii) the practical understanding of situations, which builds on and acquires knowledge, and (iii) the ability to mobilize networks of actors around the same situations through co-responsibility and sharing of what is at stake in each situation (ZARIFIAN, 2001).

According to Johnson et al. (2006), in several studies cultural distance is reported to have an impact on operational processes and results of multinational as well as transnational 


\section{AWARENESS IN THE DEVELOPMENT OF INTERCULTURAL COMPETENCES AND EXISTING RELATIONSHIPS BETWEEN ATTITUDES, SKILLS AND KNOWLEDGE \\ DOI: http://dx.doi.org/10.5007/1983-4535.2020v13n1p1}

corporations, as illustrated by Hofstede (1991). Frequently, research results associate cultural distance with the difficulties encountered in the destination country, highlighting differences in values of the language, the economy and its legal and political systems.

Complementing this idea, Johnson et al.(2006) carried out a wide bibliographic review on intercultural competence, reckognising that the literature dedicated to multicultural management has still paid little attention to the definition of the concept of intercultural competence.

Considering this approach, Bird et al. (2010) argued that intercultural competence is considered essential for the development of the global labor market, as the demand for collaboration and coordination capabilities of leaders increase in the sense of perceiving, interpreting and acting in order to reach organizational objectives. Moreover, the authors emphasize that the concept of intercultural competence and global leadership is related and thus complement each other in some aspects.

According to Berninghausen et al (2009), intercultural competence is the necessary condition for an adequate, successful and mutually satisfactorily communication and cooperation between people of different cultures. The development of intercultural competence becomes a necessary requirement for foreigners in order to adapt to the workplace, university and private life. Consequently, this suggests a challenge to universities, as universities require to offer means of facilitating the development of intercultural competence, providing presentations and seminars on communication and intercultural learning in order to obtain a better adaptation of foreign students.

Concepts by Johnson et al. (2006) and Berninghausen et al. (2009) show that communication and adaptability to other cultures are requirements for the development of intercultural competence, as well as flexibility in attitudes due to cultural differences.

In this sense, it is worth mentioning Pascarella's (1985) model, which refers to the organizational and structural characteristics about the institution and the student's traits exert together mutual influence. Equally important, Pascarella's model is critical and adequately analyzes multi-institutional data for the purposes of specific and individual levels. Another model that deserves attention is Deardorff (2006), who emphasizes that specific attitudes, knowledge and skills can be used as criteria and indicators of each of the domains (cognitive and affective), which is useful for the evaluation of these abilities within the training context. 


\section{AWARENESS IN THE DEVELOPMENT OF INTERCULTURAL COMPETENCES AND EXISTING RELATIONSHIPS BETWEEN ATTITUDES, SKILLS AND KNOWLEDGE \\ DOI: http://dx.doi.org/10.5007/1983-4535.2020v13n1p1}

In addition to the presented models, Schnabel (2015) measures aspects related to intercultural competence, such as: a) focus on skills; B) integrate items that are formulated as behavioral situations and alternatives; $\mathrm{C}$ ) is able to evaluate the development of intercultural competences through different periods of time; D) is independent of a specific cultural context; E) have less biases of existing instruments; F) meet psychometric standards.

\subsection{THE ASSESSMENT OF INTERCULTURAL COMPETENCE (ACI)}

Fantini initiated research related to intercultural skills in the 1980s. In 2007, he developed "Assessment Tools of Intercultural Communicative Competence", e.g. involving the exploration of language acquisition of bilingual children, new forms of cultural teaching, as well as a model of intercultural competence.

Furthermore, it is worth mentioning that Fantini (2007) served as an advisory member of a panel that developed foreign language norms in the United States of America (USA) besides leading the society for Intercultural Education, Training and International Research.

In the context of intercultural competence, given the relevance of Fantini (2007), this study is guided, mainly, by Fantini's theoretical/methodological model. It can be emphasized that there are different individuals who bring different goals and motivations to the intercultural experience, and thus result in different degrees of competence. Some individuals wish to attain native behavior as encountered in the host culture; others may simply aim for content expansion to gain acceptance, while for otherrs mere survival may suffice. Generally, the higher the involvement and exposure to a second language and its cultural aspects, the greater the effects on one's own native language.

Fantini's model of intercultural competence is based on the following factors. First, the model quantifies four components, i.e., an individual's knowledge, attitudes, abilities and awareness with an equal weighting score. Second, the model accounts for the measurement of two distinct periods in time. At the beginning and at end of the exchange, thus evidencing the evolution of the components throughout the exchange. Third, the model allows the comparison of students of different nationalities, since the questionnaires used as instruments of data collection, present situations perfectly applicable in several cultural contexts.

According to Fantini (2007), the desire to be truly involved in the new culture, during a transcultural stay, promotes the transcendence and transformation one's original way of 


\section{AWARENESS IN THE DEVELOPMENT OF INTERCULTURAL COMPETENCES AND EXISTING RELATIONSHIPS BETWEEN ATTITUDES, SKILLS AND KNOWLEDGE \\ DOI: http://dx.doi.org/10.5007/1983-4535.2020v13n1p1}

perceiving, knowing and expressing about the world. Consequently, the development of intercultural skills improves along this process. But what exactly is intercultural competence?

Although this term can be considered widely used today, there is no definite consensus on what it truly stands for. There are several distinct perspectives that deal with 'intercultural competence', namely, global knowledge, cultural sensitivity, certain communication skills in different languages, the ability to study in a foreign country as well as the adaptation in a different cultural reality that ususally requires cross cultural preparation in advance of the actual visit (FANTINI, 2007).

Along this view, Fantini further emphasizes that the global view of the world is shaped in the minds of people, aided and influenced by the linguistic system to which individuals are exposed to from birth onwards. It is important to note that speaking a second language shapes this development since language education and intercultural communication are indescribably linked (FANTINI, 2012).

Having said that, it is shown that when a student is willing to learn a foreign language, an intercultural perspective is presented which, according to Fantini (2006), leads to the overcoming of the limitations of the worldview arising from his native culture. Figure 1 shows the structure of the Intercultural Competence Assessment (ACI) model of Fantini (2007).

Figure 1 The structure of the ACI model of Fantini (2007)

\begin{tabular}{|l|l|l|}
\hline \multicolumn{1}{|c|}{ Section } & Number of Items & \multicolumn{1}{c|}{ Examples } \\
\hline $\begin{array}{l}\text { 1 About the } \\
\text { respondent }\end{array}$ & 37 & Name, nationality, sex, level of education, last cultural relations \\
\hline $\begin{array}{l}\text { 2 Personal } \\
\text { characteristics }\end{array}$ & 28 & $\begin{array}{l}\text { Evaluates how students consider in their own cultures and how } \\
\text { they believe they will be received in another culture }(0-5), \\
\text { characteristic examples: 1. intolerant 2. flexible 3. patient 4. lack } \\
\text { of sense of humor 5. tolerant }\end{array}$ \\
\hline $\begin{array}{l}\text { options } \\
\text { M Proficiency in } \\
\text { language }\end{array}$ & 18 & $\begin{array}{l}\text { It assesses the level of interest and characterizes the motivation } \\
\text { for culture in the foreign country (0-5). Example of interest } \\
\text { levels: 1. Before arriving 2. During the exchange example } \\
\text { motives: 1. Sometimes wanted to go back to the house 2. Desire } \\
\text { for better accommodation }\end{array}$ \\
\hline $\begin{array}{l}\text { 5 Communication } \\
\text { Styles }\end{array}$ & 15 & $\begin{array}{l}\text { Describes proficiency at the beginning and end of the exchange } \\
\text { (yes or no) example of proficiency items 1. no skill 2. able to } \\
\text { meet immediate needs with memorized phrases }\end{array}$ \\
\hline
\end{tabular}




\begin{tabular}{|l|c|l|}
\hline \multicolumn{1}{|c|}{ Section } & Number of Items & \multicolumn{1}{c|}{ Examples } \\
\hline $\begin{array}{l}\text { 6 Intercultural } \\
\text { áreas }\end{array}$ & 12 & $\begin{array}{l}\text { Evaluate specific situations (0-5) for example: I was able to } \\
\text { communicate in Spanish with a) my host family b) my } \\
\text { colleagues in the foreign country c) other natives in the foreign } \\
\text { country }\end{array}$ \\
\hline $\begin{array}{l}7 \text { Intercultural } \\
\text { skills }\end{array}$ & $\begin{array}{l}\text { Evaluates intercultural skills at the beginning and end of } \\
\text { exchange on knowledge, attitudes, skills and awareness (0 - 5) } \\
\text { example of the knowledge component: I was able to engage } \\
\text { important aspects of language culture in the foreign country } \\
\text { with my own. Example of the attitudes component: I } \\
\text { demonstrated a desire to interact with members of my behavior, } \\
\text { clothes, etc. As appropriate to avoid offending my hosts, an } \\
\text { example of the awareness component: I realized the importance } \\
\text { of my negative reactions }\end{array}$ \\
\hline
\end{tabular}

Source: Adapted from Fantini (2007).

Based on Fantini's perspective, intercultural competence can be defined as a group of skills needed to effectively and appropriately interact with others who are linguistically and culturally different from each other. Components such as knowledge, attitude, skills and awareness are taken into account for the formation of this concept of intercultural competence.

(I) Knowledge - reflects what students know about the own culture and culture of the exchange country. Aspects related to language, customs, traditions, geopolitical and historical aspects are considered. This is corroborated by Ruas (2005), who emphasizes competence as a process of capacity development in the form of knowledge. It therefore refers, to the capacity of the individual to recognize that knowledge is individual in nature and thus uniquely dependent on the individual. In this sense, Fantini (2007) refers to knowledge from an individual and social interaction, which perpetuates between groups of a particular country/nation. In this component there is dependence on the initial stage of exchange, on the ability to describe and compare interactional behaviors related to language and culture, based on previous knowledge about the country of exchange.

(i) Attitudes - characterizes the degree of immersion of the student in the exchange country, taking into account the capacity for interaction, learning, reflection, understanding and sensitivity, based on the culture of origin, highlighting how this culture is received in the exchange country. In addition, the model assesses how foreign students interact with local students and the degree of integration in between local and foreign students, as some individuals might prefer to mainly act within the international group, without the interaction with native students.

(ii) Skills - reflects the students' ability to adapt during the exchange. As newly acquired information will be put straight into practice, in order to obtain a better integration in the foreign country and the ability to relate this new information to the native culture. It concerns the degree of learning of the language of the exchange country, In other words, whether the student can efficiently communicate in an oral 
and written manner, or if the subject is limited to basic communication, with some difficulty of understanding. In addition, the acquisition of general environmental factors are analysed such as for example the notion of street safety, the operation of public transport and the documentation necessary for visa regulations in the exchange country which can be linked to how the students used this new information for adaptation in the exchange country.

(iii) Awareness - It portrays the students' perception about the level of intercultural development and its relation with the knowledge, attitudes and skills components in its development. Aspects such as the level of intercultural development, ability to solve problems, perception about cultural diversity and how to deal with differences are some of the aspects reflected in this section. It refers to the ability to self-reflect on the learning during the exchange period. In this element the student evaluates his notion of evolution throughout the exchange, as well as evaluating the factors related to the other components.

The diversity of terms related to the notion of intercultural competence refers to the thematic perspective in which it is employed. Most terms allude to only limited aspects to a more complex phenomenon. In order to transcend one's own native competence and worldview and move on to another system, to any degree, it requires the simultaneous development of intercultural competence, which results in the production of unique perspectives arising from the interaction of at least two or more subjects (FANTINI, 2007).

\section{METODOLOGY}

The conductive research methodology of this study will be evidenced based on the following parameters: type of research, sample identification, data collection and data processing.

This research is defined as quantitative in the steps of data collection and analysis. As a type of research, Collis and Hussey (2005) use the classification according to their objective that can either be exploratory, descriptive analytical or predictive. Regarding this paper's objective, this research is descriptive, since its objective is to describe the behavior of the phenomena, through the evaluation and reporting of the characteristics of the focused problem. In relation to the field research, primary data were collected by the usage of questionnaires with exchange students at UFC. The selected sample of this research is composed of foreign students who spend a minimum of five months, in between 2008 and 2015 at the university.

Within the given period, in total 279 German and Spanish students spend at least one semester at the UFC, with in total 159 students participating in the study thus overall covering 
$57 \%$ of all exchange students. The sample selection was non-random based on the ease of access to identified students, using the databases of several institutions such as of the Coordination of International Affairs (CAI), the UFC's Intercambio Support Program (PAI) , Alumni network of the Technical University of Munich(Technische Universitat Munchen), as well as the UNIBRAL network of the Applied University of Bremen and the Applied University of Colone.

On the one hand, the data collection was carried out in person, with the application of 101 questionnaires in Germany in the months of September and October 2015, and on the other through 58 online questionnaires with the Spanish students at the same time.

This research uses the model "The Assessment of Intercultural Competence" (ACI: Intercultural Competence Assessment), developed and validated by Fantini (2007). This model was applied to specific intercultural situations, such as personal characteristics and intercultural skills.

The data collection instrument of this research was based on the questionnaire model of "Intercultural Abilities" that makes up the Intercultural Competence Assessment Model (ACI), developed and validated by Fantini (2007). This paper's interview is composed of 54 questions related to the four previously definded components (knowledge, attitudes, skills and awareness), where participants are asked to state their perspective retroactively at the beginning and end of the exchange. A Likert scale was selected segmented in six intervals, ranging from 0 (not applicable) to 5 (very satisfactory) for each of the periods (beginning and end) of the exchange. We also included 10 questions related to the sociodemographic profile of the sample.

The multivariate statistical data analysis is structured in four stages: (i) descriptive analysis; (ii) factorial analysis for the reduction of the number of variables (criterion of substitute variable), (iii) inferential statistics (T-Test and Mann-Whitney test), and (iiii) logistical regression.

Firstly, the descriptive analysis is used to draw the profile of the sample, as well as to identify the existing relations of awareness of the student who made the exchange. Therefore the chi-square test is applied with, where $p<0.05$ means the relationship between the variables is significant.

In the second step, it is worth highlighting the factorial analysis for factor reduction, using the Varimax rotation method. According Schawb (2007), usually the minimum 
acceptable value for the "loading factor" is 0.5; however, Fantini (2007) states in his model that the loading factor must be equal or greater than 0.6 , because a greater score than 0.6 indicates that there is a strong correlation with the other questions.

In addition, the eigenvalues of each factor are analyzed; The Bartlett sphericity test, the KMO, which ranges from 0 to 1 . As published by Hair et al. (2009), the acceptance criteria of 0.5 is applied for this part.

In the third step, we executed the student T-Test, to examine whether two samples originate from distributions that have the same average. Further the non-parametric MannWhitney test was conducted. In relation to these tests, a significance level of 0.05 was adopted for its acceptance in the analysis.

In the fourth step, the exploratory factorial analysis (AFE) is used, because this statistical technique allows exploring a set of variables, in order to identify the variables that "walk together". Thus, the AFE is pertinent, because it creates dependent and or independent variables so that they can be used in logistic regression.

In the fifth stage, logistic regression is applied, since this search seeks to verify the relationship between the dependent variable (awareness) and the independent variables (attitudes, skills, knowledge, and sociodemographic characteristics). In this technique, it can be related that the lower the degree of significance, the greater the relation of the independent variable on the dependent variable. Therefore, a significance level of less than 0.005 is used for the acceptance of the variable in the analysis.

In the next section the data analysis and their results are presented.

\section{ANALYSIS OF DATA AND RESULTS}

The sample of this research is composed of 159 foreign students from Germany and Spain. Among the German students, there are 54 female students and 47 male students, whereas among the Spanish students, the majority is male with 34 compared to 24 female students, as shown in Table 1.

Table 1 Composition of the sample by nationality and gender

\begin{tabular}{c|c|c|c}
\hline Genre & Germans & Spanish & Chi-square \\
\hline Female & 54 & 24 & \multirow{2}{*}{0.1927} \\
Male & 47 & 34 & \\
\hline Total & 101 & 58 & \\
\hline
\end{tabular}

Source: Research data. 
In relation to the area of study, the most relevant degrees among the German students are humanities and social science, while among the Spanish students, courses within science and engineering form the majority. Among the most recurrent courses, there is administration and social sciences in the case of the German participants and electrical engineering and production engineering courses are more frequent among the Spanish as illustrated in Table 2.

Table 2 Composition of the sample by nationality and area of study

\begin{tabular}{c|c|c|c}
\hline Area & Germans & Spanish & Chi-square \\
\hline Biology / Health & 16 & 10 & \\
Science \& Engineering & 24 & 35 & \multirow{2}{*}{0.0000} \\
Humanities & 36 & 4 & \\
Social Sciences & 25 & 9 & \\
\hline Total & 101 & 58 & \\
\hline
\end{tabular}

Source: Research data.

As depicted in Table 3, the number of mastered languages shows a great difference between German and Spanish students, since the vast majority of Spanish students claim to master only two languages, while most German students dominate between 3 or 4 languages. It is also detected that the second language presented by the Spanish students is mostly Portuguese, which, in this case, is the language of the exchange country delimited by this research.

Table 3 Composition of the sample by nationality and number of languages dominated

\begin{tabular}{c|c|c|c}
\hline Number of languages & Germans & Spanish & Chi-square \\
\hline 2 & 10 & 47 & \\
3 & 35 & 10 & \\
4 & 38 & 1 & 0.0000 \\
5 & 18 & 0 & \\
\hline Total & 101 & 58 & \\
\hline
\end{tabular}

Source: Research data.

It is pertinent to emphasize the chi-square $(\mathrm{p}=0.0000)$, since this value suggests a positive effect to this analysis, since the Chi-square indicator is significantly less than suggested in literature $(\mathrm{p}<0.05)$. Hence the participant selection is strongly acceptable.

Regarding the exploratory factor analysis (AFE) of the intercultural competences at the beginning of the exchange, the questions are presented, in each component, considering the greater correlation between the questions. 


\section{AWARENESS IN THE DEVELOPMENT OF INTERCULTURAL COMPETENCES AND EXISTING RELATIONSHIPS BETWEEN ATTITUDES, SKILLS AND KNOWLEDGE \\ DOI: http://dx.doi.org/10.5007/1983-4535.2020v13n1p1}

Table 4 Factor analysis for intercultural competences at the beginning of the exchange

\begin{tabular}{|c|c|c|c|c|c|}
\hline \multicolumn{2}{|c|}{ Factor } & Factorial loads & Communalities & Suitability measure & Variance explained \\
\hline \multirow{4}{*}{ Knowledge } & Before 11 & 0.747 & 0.560 & 0.710 & \multirow{4}{*}{0.580} \\
\hline & Before 12 & 0.777 & 0,600 & 0,700 & \\
\hline & Before 15 & 0.722 & 0.520 & 0.710 & \\
\hline & Before 16 & 0.786 & 0.620 & 0,700 & \\
\hline \multirow{5}{*}{ Attitudes } & Before 30 & 0.710 & 0.504 & 0.880 & \multirow{5}{*}{0,650} \\
\hline & Before 31 & 0.859 & 0,737 & 0.840 & \\
\hline & Before 32 & 0.854 & 0.729 & 0.830 & \\
\hline & Before 33 & 0.851 & 0.724 & 0.810 & \\
\hline & Before 34 & 0.741 & 0.550 & 0.860 & \\
\hline \multirow{5}{*}{ Skills } & Before 39 & 0.710 & 0.500 & 0.880 & \multirow{5}{*}{0.580} \\
\hline & Before 42 & 0.720 & 0.516 & 0.850 & \\
\hline & Before 43 & 0.810 & 0.655 & 0.810 & \\
\hline & Before 44 & 0.830 & 0.690 & 0,800 & \\
\hline & Before 45 & 0.730 & 0.533 & 0.840 & \\
\hline \multirow{5}{*}{ Awareness } & Before 47 & 0.710 & 0.500 & 0,800 & \multirow{5}{*}{0.557} \\
\hline & Before 50 & 0.720 & 0.516 & 0,800 & \\
\hline & Before 53 & 0.810 & 0.655 & 0.840 & \\
\hline & Before 58 & 0.830 & 0,690 & 0.810 & \\
\hline & Before 59 & 0.730 & 0.533 & 0.830 & \\
\hline
\end{tabular}

Source: Research data.

Table 4 shows the factorial analysis for each component of the research before the exchange. In the knowledge component, one can identify how the students evaluate their knowledge of the country of origin based on newly acquired information prior to the exchange. The questions that present a high correlation, at the beginning of the exchange, with values higher than 0.721 are 1) the perceptions of German and Spanish students, about the concept of culture, 2) the comparison of the customs typical of the country of the exchange with the customs of the country, 3) the mastery of techniques for adaptation in the foreign country, and, finally 4) the verification or rejection of the information "clichés" worldwide disseminated in the media about some behavioral patterns of the country of the exchange.

With respect to the attitudes component, the perception of actions that lead to better interaction during the exchange is measured. The questions that showed a higher correlation and hence greater contribution to the formation of this component at the beginning of the exchange, reported a factorial load greater than 0.709. In this component, the German and Spanish highlight the results to be flexible and meet the changes that each specific situation 
requires, in line with the appreciation of the complexities of communication and intercultural interaction.

Additionally, the tool analyses whether participants relativize their own values, beliefs and behaviors and seek to understand how they can be seen by someone from another culture. This involves the ability to decentralize and try to understand the differences in behaviors, values, attitudes and styles of the people of the country of the exchange, as well as to be able to interact differently contrary to common habits in the home country and reflect on the impact of these attitudes.

Findings before the exchange within the skills component reveal the perception of German and Spanish regarding factors that contribute and challenge to adapt in a foreign country at the beginning of the exchange. The questions that most contribute to the formation of this component reported values greater than 0.709. These questions emphasize the dependence level domain of the country's exchange language, perception of the appropriate use of certain expressions in different situations, from the application of forms of formal treatment to the discernment of the use of slang and more informal words with the ease or difficulty of adaptation in the country of exchange.

Finally, in the awareness component, students consider their own level of intercultural development and the individual perception of the evolution. The questions that had higher correlation values report factorial loads greater than 0.709 as determined before. German and Spanish stated what their individually aimed exposure to an intercultural exchange is and how they perceive the evolution of other exchange students, the latter either with the same or different nationality. Vice versa students were also asked to determine the level of local residents' intercultutal abilities by relating knowledge components, attitudes and skills that can either contribute or hinder the development throughout the period abroad.

Subsequently the same factorial analysis was executed at the end of the exchange; however, before the analysis was executed questions with factorial loadings below 0.6 were discarded from further analysis within the components attitudes, skills, and awareness. The factorial analysis was then executed based on the limited remaining questions, where once again questions with a lower factorial loading than 0.6 were discarded. Results are presented in Table 5. 


\section{AWARENESS IN THE DEVELOPMENT OF INTERCULTURAL COMPETENCES AND EXISTING RELATIONSHIPS BETWEEN ATTITUDES, SKILLS AND KNOWLEDGE \\ DOI: http://dx.doi.org/10.5007/1983-4535.2020v13n1p1}

Table 5 Factor analysis for intercultural competences at the end of the exchange

\begin{tabular}{|c|c|c|c|c|c|}
\hline \multicolumn{2}{|c|}{ Factor } & $\begin{array}{l}\text { Factorial } \\
\text { Loadings }\end{array}$ & Commonalities & Adequacy Measure & Explained Variance \\
\hline \multirow{4}{*}{ Knowledge } & after 13 & 0.733 & 0.560 & 0,800 & \multirow{4}{*}{0.604} \\
\hline & after 14 & 0.778 & 0.600 & 0.770 & \\
\hline & after 15 & 0.819 & 0.520 & 0.730 & \\
\hline & after 16 & 0.778 & 0.620 & 0.740 & \\
\hline \multirow{3}{*}{ Attitudes } & after 27 & 0,800 & 0.640 & 0.780 & \multirow{3}{*}{0.721} \\
\hline & after 32 & 0.882 & 0.778 & 0.650 & \\
\hline & after 33 & 0.864 & 0.746 & 0,670 & \\
\hline \multirow{3}{*}{ Skills } & after 42 & 0.848 & 0.720 & 0.730 & \multirow{3}{*}{0.580} \\
\hline & after 43 & 0.875 & 0.766 & 0.690 & \\
\hline & after 44 & 0.850 & 0.723 & 0.730 & \\
\hline \multirow{4}{*}{ Awareness } & after 46 & 0.717 & 0.513 & 0,800 & \multirow{4}{*}{0.550} \\
\hline & after 51 & 0.801 & 0.641 & 0,800 & \\
\hline & after 52 & 0.739 & 0,546 & 0.840 & \\
\hline & after 59 & 0.705 & 0.500 & 0.810 & \\
\hline
\end{tabular}

Source: Research data.

With the removal of less correlated questions, there is an overall observed increased in the factorial loading and hence correlation a was intended to determine the most important factors within the tool's componnets.

Results after the exchange within the knowledge component reveal that the students' standpoint remain unchanged highlighting the importance of using techniques to help to study the culture as well as language within the foreign country and the ability to contrast typical behaviors of native culture with the one of the exchange country. Aspects such as the recognition of cultural clashes and strategies to overcome them, have a greater importance, at the end of the exchange for the two nationalities consulted than before the exchange.

First of all, in the attitudes component the overall amount of questions dropped from five to three. Results indicate that the interaction style contrary to the experiences in the home country as well as the notion of ethical upbrining continued to have strong influence on the German and Spanish. Also, at the end of the exchange, the interest in new cultural aspects, such as understanding of values and traditions, became more relevant among students.

In skills component, as noted in the attitudes component is found at the end of exchange reduce the number of questions forming component. Previously, five questions presented significant correlation value for the component of training, now at the end of the exchange, this value dropped to three, and these questions have remained the same from the 


\section{AWARENESS IN THE DEVELOPMENT OF INTERCULTURAL COMPETENCES AND EXISTING RELATIONSHIPS BETWEEN ATTITUDES, SKILLS AND KNOWLEDGE \\ DOI: http://dx.doi.org/10.5007/1983-4535.2020v13n1p1}

beginning of the exchange. Questions regarding the techniques used to adapt in a foreign country, associated with learning the language and culture.

Finally, within the component awareness, overall one question was dropped with one question remaining with a very high correlation that is related to the individual's aimed exposure to an intercultural exchange. Items relevant to the composition of this component are aspects such as the perception of cultural diversity of the country of exchange, the perception of other foreigners and how the impact of cultural difference can influence the perception.

In the previous study by Fantini (2007), in order to measure the intercultural skills of British and Swiss students, one can identify similarities in relation to evolution presented by the Spanish and German students surveyed in this research. In the knowledge component, the question about the ability to contrast aspects of the culture and language of the country of exchange with the country of origin also had a strong contribution to the formation of the knowledge component of the British and Swiss students, as happened in the case of training this component for Spanish and German students.

In the attitudes component, it appears that the question related to the notion of ethical implications of choices, was also important for the formation of the attitudes with the British and Swiss students. In relation to the German and Spanish students, this question also contributes to the formation of attitudes component, especially among German students.

The use of techniques for better adaptation as well as learning of language and culture in a foreign country, as reported in the study Fantini (2007) with the British and Swiss students is also confirmed among Spanish and German students highlighting this item as the one that contributes most to the formation of the skills component. Regarding the awareness component, the question related to perception of cultural diversity of the country of the exchange presented an important contribution to the formation of this component among British and Swiss students as well, that also demonstrated a strong contribution in shaping the awareness component for Spanish and German students.

Regarding Fantini's study (2007), it appears that the number of questions with factor loadings above 0.6 was higher among the British and Swiss student than the results presented by the Spanish and German students. Comparing the individual responses of the German and Spanish students, one sees a greater similarity of the responses of German students than the Spanish students compared the responses of British and Swiss students. 


\section{AWARENESS IN THE DEVELOPMENT OF INTERCULTURAL COMPETENCES AND EXISTING RELATIONSHIPS BETWEEN ATTITUDES, SKILLS AND KNOWLEDGE \\ DOI: http://dx.doi.org/10.5007/1983-4535.2020v13n1p1}

Table 6 Comparison of intercultural skills at the beginning and end of the exchange of German students

\begin{tabular}{|c|c|c|c|c|c|}
\hline Competence & Statistic & Before & After & Paired t-test & Wilcoxon test \\
\hline \multirow{5}{*}{ Awareness } & Average & 0.3088 & 0.4545 & \multirow{5}{*}{0.0000} & \multirow{5}{*}{0.0000} \\
\hline & Detour & 0.1963 & 0.2074 & & \\
\hline & 1st Quartile & 0.1987 & 0.3569 & & \\
\hline & median & 0.2973 & 0.5000 & & \\
\hline & 3rd Quartile & 0.4019 & 0.5091 & & \\
\hline \multirow{5}{*}{ Attitudes } & Average & 0.2968 & 0.5504 & \multirow{5}{*}{0.0000} & \multirow{5}{*}{0.0000} \\
\hline & Detour & 0.1429 & .2133 & & \\
\hline & 1st Quartile & 0.1835 & 0.4319 & & \\
\hline & median & 0.2967 & 0.6667 & & \\
\hline & 3rd Quartile & 0.3571 & 0.6667 & & \\
\hline \multirow{5}{*}{ Knowledge } & Average & 0.4117 & 0.6004 & \multirow{5}{*}{0.0000} & \multirow{5}{*}{0.0000} \\
\hline & Detour & 0.1831 & .1954 & & \\
\hline & 1st Quartile & 0.3333 & 0.4435 & & \\
\hline & median & 0.3333 & 0.6557 & & \\
\hline & 3rd Quartile & 0.4904 & 0.7633 & & \\
\hline \multirow{5}{*}{ Skills } & Average & 0.3018 & 0.5850 & \multirow{5}{*}{0.0000} & \multirow{5}{*}{0.0000} \\
\hline & Detour & 0.1764 & 0.3372 & & \\
\hline & 1st Quartile & 0.1655 & 0.3354 & & \\
\hline & median & 0.2511 & 0.6518 & & \\
\hline & 3rd Quartile & 0.4322 & 0.8482 & & \\
\hline
\end{tabular}

Source: Research data.

According to Table 6, among German students, all components were increased in between the beginning and end of the exchange with emphasis on the components attitudes and skills. It is also worth mentioning the standard deviation is defined by with little variation within the awareness component, while the skills component's standard deviation nearly doubles. Also, the Wilcoxon paired test proves that there is a difference between the responses of German students, that were gathered at the beginning and end of the exchange.

Table 7 presents the same statistics for the Spanish students. The difference between the responses at the beginning and end of the exchange is also proven through the Wilcoxon test; however, the knowledge component value was different from the average (0.0000). Thus, the difference at the beginning and end of the exchange is less dominant than in the remaining three components. This confirms the second hypothesis which states that the knowledge component has the least influence on awareness. This is in agreement with Fantini's study that also showed the knowledge component has less influence on the awareness of British and Swiss students. Also noteworthy is the decrease in the average awareness component, from 
the beginning to the end of the exchange, which allows to deduce that among Spanish students the notion of awareness during the exchange is lower than that observed among German students.

Table 7 Comparison of intercultural skills at the beginning and end of the exchange of Spanish students

\begin{tabular}{c|c|c|c|c|c}
\hline Competence & Statistic & Before & After & Paired t-test & Wilcoxon test \\
\hline \multirow{5}{*}{ Awareness } & Average & 0.6615 & 0.3835 & & \\
& Detour & 0.1048 & 0.1340 & & 0.0000 \\
& 1st Quartile & 0.6006 & 0.3674 & 0.0000 & \\
& median & 0.6006 & 0.3924 & & \\
& 3rd Quartile & 0.6992 & 0.5000 & & 0.0000 \\
Attitudes & Average & 0.5066 & 0.6141 & & \\
& Detour & 0.1193 & 0.0848 & & \\
& 1st Quartile & 0.4756 & 0.5681 & 0.0000 & \\
& median & 0.4756 & 0.6667 & & 0.3048 \\
& 3rd Quartile & 0.5353 & 0.6667 & & \\
\hline \multirow{5}{*}{ Knowledge } & Average & 0.4220 & 0.4501 & & \\
& Detour & 0.1265 & 0.1963 & & \\
& 1st Quartile & 0.3333 & 0.3279 & 0.2779 & \\
& median & 0.4170 & 0.4190 & & \\
& 3rd Quartile & 0.4904 & 0.5646 & & \\
\hline \multirow{5}{*}{ Skills } & Average & 0.7018 & 0.9108 & & \\
& Detour & 0.1653 & 0.1446 & & \\
& 1st Quartile & 0.6253 & 0.8482 & 0.0000 & \\
& median & 0.6253 & 1.0000 & & \\
& 3rd Quartile & 0.8697 & 1.0000 & & \\
\hline
\end{tabular}

Source: Research data.

The use of regression aims to investigate the relationship of the independent variables: intercept, attitudes, skills, knowledge, knowledge area (Science \& Engineering) area of knowledge (Humanities), area of knowledge (Social Sciences), Gender (Male), nationality (Spanish) and Number of languages that are depending on the dependent variable awareness. Among the Spanish and Germans students, findings reveal that the knowledge component positively influences the awareness of students at the beginning and end of the exchange, while the skills component starts to negatively influence the awareness at the end of the exchange as depicted in Table 8. The attitudes component at the beginning of exchange negatively influences the awareness of students and at the end of the exchange, shall influence positively, confirming the third hypothesis which states that the attitudes and skills component have different correlations with the awareness component. In the previous study 
Fantini (2007), the Attitudes and Skills component also showed different behavior among British students and Swiss, however both have shown positive growth and neither had a negative influence among these students.

Table 8 Awareness of regression as the dependent variable

\begin{tabular}{l|c|c}
\hline \multicolumn{1}{c|}{ Variables } & Start & End \\
\hline Intercept & $0.1587^{*}$ & $0.1858^{* *}$ \\
Atitudes & -0.0428 & $0.1911^{* *}$ \\
Skills & $0.1531^{*}$ & $-0.2011^{* * *}$ \\
Knowledge & 0.1388 & $0.1794^{* *}$ \\
Field of knowledge (Science \& Engineering) & 0.0241 & -0.0564 \\
Field of knowledge (Humanities) & 0.0707 & 0.0281 \\
Field of knowledge (Social Sciences) & 0.0610 & 0.0204 \\
Male gender & $0.0485^{*}$ & 0.0048 \\
Spanish nationality & $0.3074 * * *$ & $0.1058^{* *}$ \\
Number of languages & -0.0029 & $0.0466^{* *}$ \\
\hline test F & $19.8300^{* * *}$ & $5.9370^{* * *}$ \\
$\mathrm{R}^{2}$ & 0.545 & 0.2639 \\
$\mathrm{R}^{2}$-adjusted & 0.518 & 0.2195 \\
\hline
\end{tabular}

Significance level: $1 \%(* * *), 5 \%(* *)$ and $10 \%(*)$

Source: Research data.

Regarding the first hypothesis, it is confirmed by the presented regression results that the number of mastered languages influence the development of the awareness component over the exchange as at the beginning of the exchange there is a negative influence on awareness but during the exchange this influence becomes positive. According to Fantini (2007), the domain of a second language makes the individual more gifted to compare differences and similarities with the native language, as well as easing the communication in the local language, and thus facilitates the immersion in the exchange country's culture.

It is pertinent to emphasize the research by Fantini (2007), generate's equal results with regards to the knowledge component which positively influences the awareness of students at the beginning and end of the exchange. The same findings are also in agreement with Fantini's results on the attitude component; however, Regarding the skills component's findings of this study on Spanish and German students, findings are inhomogeneous from Fantini's results at the end of the exchange the component influenced awareness negatively. 


\section{AWARENESS IN THE DEVELOPMENT OF INTERCULTURAL COMPETENCES AND EXISTING RELATIONSHIPS BETWEEN ATTITUDES, SKILLS AND KNOWLEDGE \\ DOI: http://dx.doi.org/10.5007/1983-4535.2020v13n1p1}

\section{FINAL REMARKS}

This research aimed to examine how the perception of exchange students on their skills, knowledge and attitudes influence their awareness.

Regarding the first specific goal - identify intercultural competencies developed by the German and Spanish students - among German students, all components were increased in between the beginning and the end of the exchange with emphasis on the attitude and skills component. It is worth mentioning also the standard deviation is with little variation for the awareness component while the skills component's standard deviation nearly doubles.

On the second specific goal, i.e., to characterize the sociodemographic profile of the German and Spanish students, according to the level of awareness of the exchange it is worth mentioning the research sample tht was composed of 159 foreign students. Among the German students, there are 54 female and 47 male students, while among Spanish students there are 24 female and 34 male students.

Regarding the study environment, degrees in humanities and social sciences are more prominent for German participants, while the majority of the Spanish students degree is within sciene and engineering. Among the most recurrent courses, there is administration and social sciences of Germans participants and electrical engineering and production engineering of the Spanish.

The amount of dominated languages shows a significant divergence between German and Spanish students, because the vast majority of Spanish students master two languages, while most German students are able to speak 3 or 4 languages.

Regarding the third specific objective, i.e., to analyze the relationship during the exchange and the components that make up the model of Fantini's Intercultural Competence Assessment framework (knowledge, attitudes and skills form awareness); findings reveal that the knowledge component positively influences the awareness of students at the beginning and end of the exchange, while the skills component starts to negatively influence the awareness at the end of the exchange for German and Spanish students. Contrarily, the attitudes component negatively influenced the awareness of students at the beginning of exchange, whereas at the end of the exchange there was a positiv influence observable.

With regards to limitations and difficulties encountered over the course of research, we would like to highlight the great length of the questionnaire which prevented a greater number of respondents. Therefore, it is expected that this research will contribute to empirical and 
conceptual studies on intercultural competence, as well as the incentive for Brazilian universities' policies to undergo a process of internationalization through conducted research with their exchange students.

\section{REFERENCES}

Adler, Nancy; Bartholomew, Susan. Managing. (1992). Globally Competent People. Academy of Management Executive, v. 6, n. 3, p. 52-65.

Berninghausen, Jutta; Gunderson, Connie; Kammler, Eva; Kühnen, Ulrich; Schönhagen, Renate. (2009). Lost in transnation: Towards an Intercultural Dimension on Campus. Centre for Intercultural Management (ZIM), Bremen.

Bhandari, R., \& Blumenthal, P. (2011). International students and global mobility in higher education: National trends and new directions. New York: Palgrave Macmillan.

Bird, Allan; Mendenhall, Mark; Stevens, Michael J; Oddou, Gary. (2010). Defining the Content Domain of Intercultural Competence for Global Leaders. Journal of Managerial Psychology, v. 25, n. 8, p. 810-828.

Collis, J; Hussey, R. (2005). Pesquisa em Administração: Um guia prático para aluno de graduação e pós-graduação. Porto Alegre: Bookman.

Deardorff, D. (2006). Identification and Assessment of Intercultural Competence as a Student Outcome of Internationalization. In Journal of Studies in Intercultural Education, 10, 241 266.

Fantini A. E. (2007). "Assessment Tools of Intercultural Communicative Competence" in St Louis. MO: Center for Social Development Washington University, 2007.

Fantini A. E. (2006). Exploring and assessing intercultural competence. Federation EIL, Brattleboro, 2006.

Fantini, A. E. (2012). Language. An essencial component of intercultural communicative competence. In: JACKSON, Jane editor. The Routledge Handbook of Langauge and Intercultural Communication. Oxon: Routledge, p.264-278.

Gil, Antonio Carlos. (1999). Métodos e técnicas de pesquisa social. 5.ed. São Paulo: Atlas.

Guitel, Virginia.(2006). Intercultural or Cross Cultural Management? The confirmation of the research field and the issue concerning the definition and the development of an intercultural competency for expatriates and international managers. Revista Economia e Gestão (E\&G), Belo Horizonte, v.6. n. 12, jan.

Hofstede, Geert. (1991). Cultures and Organizations: software of the mind. England: McGRAW-Hill.

Hair, J. F; Anderson, R. E.; Tatham, R. L. \& Black, W. C. (2005). Análise Multivariada de 
Dados; Tradução:. Adonay S.Sant'anna e Anselmo Chaves Neto. 5 ed Porto Alegre:Bookman.

Homem, Ivana D.; Tolfo, Suzana R. (2004). Gestão Intercultural: perspectivas para o ajustamento de executivos expatriados. In: ENCONTRO NACIONAL DOS PROGRAMAS DE PÓSGRADUAÇÃO EM ADMINISTRAÇÃO, 28. Curitiba, Anais... Curitiba.

Johson, James P.; Lenartowicz, Tomasz; APUD, Salvador. (2006). Cross-Cultural Competence in International Business: toward a definition and a model. Journal of International Business Studies, Washington, United Kingdom, v. 37, n. 4, p. 525-543.

Knight, Jane. (2004). Internationalization Remodelled: Definition, Approaches, and Rationales. Journal of Studies in International Education. Sage Publications, v.8, n.1, p.531.

Lafromboise, Tereza; Coleman H. L.; Gerton, J. (1993). Psychological Impact of Biculturalism: evidence and theory. Psychological Bulletin, United States, v. 114, n. 3, p. 395-412.

Miura, I. K. (2006). O processo de internacionalização da Universidade de São Paulo: um estudo de caso de três áreas do conhecimento. Tese (Livre Docência) - Faculdade de Economia, Administração e Contabilidade da Universidade de São Paulo, Ribeirão Preto.

Morosini, M. C. (2006). Estado do conhecimento sobre internacionalização da educação superior- conceitos e práticas. Educar em Revista, Curitiba, n.28, p.1-9, jul./dez.

PAI, Relatório. Programa de Apoio ao Intercambista (PAI) da Universidade Federal do Ceará. (2015). Disponível em: https://paiufc.wordpress.com/ Acesso em: 31 Ago. 2015.

Pascarella, E. T. (1985). College environmental influences on learning and cognitive development: A critical review and synthesis. In J. Smart (Ed.). Higher education: Handbook of theory and research (Vol.1, pp. 1-64). New York: Agathon.

Pascarella, E. T., \& Terenzini, P. T. (2005). How college affects students (Vol. 2): A third decade of research. San Francisco: Jossey-Bass.

Ray, B. (2002). As Competências Transversais em Questão. Porto Alegre: ArtMed.

Schanbel, D., Kelava, A., Seifert, L., \& Kuhlbrodt, B. (2015). Konstruktion und Validierung eines multimethodalen berufsbezogenen Tests zur Messung interkultureller Kompetenz [Development and validation of a job-related multimethod test to measure intercultural competence]. Diagnostica. Advance online publication.

Schwab, A.J. (2007). Eletronic Classroom.[Online]. Disponível em:

$<$ http://www.utexas.edu/ssw/eclassroom/schwab.html> Acesso em: [21 nov. 2015]

Spitzberg, B. \& Changnon, G. (2009). Conceptualizing Intercultural Competence. In D. Deardorff (Ed.), The SAGE Handbook of Intercultural Competence (pp. 1-52). Thousand Oaks, CA: SAGE Publications.

Spitzberg, B. \& Cupach, W. (1984). Interpersonal Communication Competence. Beverly 
Hills, CA.

Streiner, D. L. (2003). Being inconsistent about consistency: when coefficient alpha does and doesn't matter. Journal of Personality Assessment. v. 80, p. 217-222.

Stromquist, N. P. (2007). Internationalization as a response to globalization: Radical shifts in university environments. Higher Education, v. 53, n.1, p. 81-105.

Vergara, S. C. (2009). Projetos e relatórios de pesquisa em administração. São Paulo, Atlas.

Woolf, M. (2010). Another Mishegas: Global citizenship. Frontiers: The Interdisciplinary

Journal of Study Abroad, 19, 47-60. 